\title{
Barley yellow dwarf virus-PAV management using seed-treatment with the insecticide imidacloprid
}

\author{
Asma Najar ${ }^{1 *}$, Ibtissem Ben Fekih ${ }^{1}$, Hajer Ben Ghanem ${ }^{2}$, Safaa G. Kumari ${ }^{3}$ and Arvind Varsani ${ }^{4}$ \\ (1) Plant Protection Laboratory of National Institute of Agricultural Research of Tunisia, University of Carthage, Street Hédi \\ Karray, 1004 El Menzah, Tunisia, Email: asmanajara@yahoo.fr; (2) Field Crop Laboratory of National Institute of \\ Agricultural Research of Tunisia, University of Carthage, Street Hédi Karray, 1004 El Menzah, Tunisia; (3) International \\ Center for Agricultural Research in the Dry Areas (ICARDA), Terbol Station, Beqa'a valley, Zahla, Lebanon; (4) The \\ Biodesign Center for Fundamental and Applied Microbiomics, Center for Evolution and Medicine, School of Life sciences, \\ Arizona State University, Tempe, AZ 85287-5001, USA.
}

\begin{abstract}
Najar, A., I. Ben Fekih, H. Ben Ghanem, S.G. Kumari and A. Varsani. 2017. Barley yellow dwarf virus-PAV management using seed-treatment with the insecticide imidacloprid. Arab Journal of Plant Protection, 35(3): 178-184.

This research aimed to investigate the effectiveness of the insecticide imidacloprid as seed treatment against Barley yellow dwarf virus-PAV (BYDV-PAV) infection in barley. Artificial inoculation of resistant (QB 813-2) and susceptible (Manel, Rihane and Cyclon) barley cultivars with BYDV-PAV under field conditions was conducted through the bird cherry-oat aphid (Rhopalosiphum padi). Following inoculation, virus incidence was monitored on the various cultivars, and growth parameters such as plant height, biomass, grain yield and thousand seed weight were measured. Seed treatment with imidacloprid, was applied at concentrations of $0.7,1.4$ and $2 \mathrm{~g}$ a.i $/ \mathrm{kg}$ seed. The highest reduction in BYDV incidence was observed after treatment with the concentration of $1.4 \mathrm{~g} \mathrm{a.i} / \mathrm{kg}$ seed. The results also indicated that the $1.4 \mathrm{~g}$ a.i/kg seed treatment significantly reduced the impact of BYDV-PAV infection on plant height for the susceptible cultivars Manel and Cyclon. An improvement in the biomass, grain yield and thousand kernels weight was recorded after imidacloprid treatment of the susceptible cultivars at the concentration of $1.4 \mathrm{~g}$ a. $1 / \mathrm{kg}$ seed, and this concentration can be considered an economic practice for BYDV management in barley fields at locations where BYDV incidence is high.
\end{abstract}

Keywords: Barley, BYDV-PAV, imidacloprid, seed-dressing, virus disease management.

\section{Introduction}

Barley yellow dwarf viruses (BYDVs) (family Luteoviridae) are globally the most damaging virus diseases of cereals $(6,28)$. The most important of these viruses is Barley yellow dwarf virus-PAV (BYDV-PAV), Barley yellow dwarf virus-MAV (BYDV-MAV) (genus Luteovirus), and Cereal yellow dwarf virus-RPV (CYDVRPV) (genus Polerovirus) (14, 24, 25, 28). Sitobion avenae F. and Rhopalosiphum padi L. are the two main aphid species recognized to transmit BYDVs efficiently $(11,29)$. Thus, occurrence of these aphids in cereal fields may lead to the establishment and dissemination of BYDVs.

In Tunisia, barley is among the important economic crops and plays a key role in the country's agri-food sector. Commonly, barley is sown during early November in Tunisia. During the early stage of vegetative growth, the plants are most susceptible to BYDVs infection and significant numbers of winged aphids were often observed in barley fields in Tunisia (4). This vulnerable vegetative growth stage in early winter with mild temperature offers a suitable environment for aphid infestation, and thus leads to primary spread of viral diseases. Previously, the impact of aphid infestation during early and mid-vegetative stages on the establishment of primary and secondary spread of barley-associated viral diseases was highlighted earlier

http://dx.doi.org/10.22268/AJPP-035.3.178184

(C) 2017 Arab Society for Plant Protection الجمعية العربية لوقاية النبات
(11). Other studies in Tunisia reported the wide occurrence of BYDVs in barley, reaching $30 \%$ incidence when infection starts during early growth stage of the plant (2, 19). Earlier virus surveys of barley fields in Tunisia reported the natural occurrence of BYDV-PAV as the predominant virus species on cereal crops (16). Several methods are reported for BYDVs management such as: (i) cultural management based on high plant density, since winged aphid vectors have preference to land in fields with low plant density (21); (ii) timely seeding, based on delayed sowing to avoid peak of aphid flights (3); and (iii) Genetic resistance, based on the selection and use of BYDVresistant cultivars (9). Among the insecticides used to control virus vectors, imidacloprid a neonicotinoid representing the highest selling insecticide worldwide (13), was successfully used as a seed treatment to control insect pests of several crops such as sugar beet, maize and vegetables (1) and applied early in the season. This insecticide is commonly applied to control sucking insects such as aphids, thrips, plant hoppers, some coleopteran and some lepidopteran pest species $(7,8,30)$. Several studies reported the benefit of seed treatment to protect chemical molecules from rain and UV degradation beside the reduction of labor cost (23). However, few studies investigated the effect of imidacloprid in reducing BYDV incidence on cereal crops through aphid control (18). Within this context, we carried out this study to assess, under field conditions, the effectiveness of the imidacloprid as seed treatment against $R$. padi to reduce BYDV-PAV infection. The major aim was to define the appropriate 
economic concentration of imidacloprid as seed treatment applied mainly to barley varieties commonly sown by Tunisian farmers.

\section{Materials and Methods}

\section{Plant material}

Four barley cultivars (Manel, Rihane, Cyclon and QB 8132 ) were used in this study. Manel and Rihane are common Tunisian cultivars that are high yielding but susceptible to BYDV infection. Cyclon and QB 813-2 (+ Yd2) both provided by ICARDA, served as susceptible and resistant control to BYDV infection, respectively.

\section{Field trial}

Field experiments were conducted in the 2003/2004 cropping season at the experimental station in Oued Beja (North of Tunisia) of the National Agricultural Research Institute of Tunisia (INRAT). Annual fertilization was based on broadcasting DAP (100 kg/ha) one week prior to sowing and two applications of urea $(75 \mathrm{~kg} / \mathrm{ha})$ during the 3-leaf stage and at early tillering. Before tillering, weed control was performed using the herbicides Illoxan (2 1/ha) against monocots and Sansac (0.8 1/ha) against broad-leaf weeds. Faba bean was the previously cultivated crop in the experimental field used for this study.

\section{Seed treatments and experimental setup}

The insecticide imidacloprid (N-\{1-[(6-Chloro-3-pyridyl) methyl]-4,5-dihydroimidazol-2-yl \}nitramide) registered worldwide, mixed with starch as an additive was evaluated for seed-treatment application. Seeds were coated with imidacloprid at the rate of $0.7,1.4$ and $2.0 \mathrm{~g}$ a.i $/ \mathrm{kg}$ seed. Two groups of untreated seeds were included: (i) virusinoculated at 2-3 leaf-stage (0) and (ii) non-inoculated (Control). The imidacloprid treatments were the main factor evaluated and the barley cultivars were the sub-factor. The adopted design included three blocks; each block included five sub-blocks. Each sub-block was divided into four experimental units to accommodate the tested cultivars. For each treatment, around 40 seeds were sown in four rows (1.5 m long) and $25 \mathrm{~cm}$ apart.

\section{BYDV isolate maintenance}

The BYDV-PAV Tunisian isolate used in this study was previously identified in infected barley plants collected from the Cap-Bon region, Tunisia (19). This isolate was maintained on Manel cultivar through successive serial aphid (Rhopalosiphum padi) transfer.

\section{Aphid vector rearing}

$R$. padi, known for its high efficiency in transmitting BYDV-PAV (20) was used in this study. Aphid rearing was initiated by using apterous aphids fed on nutritive media (20\% sucrose) through a parafilm membrane as previously described (5). Petri dishes, $90 \mathrm{~mm}$ diameter, were used as support to assure the first-instar nymphs production. Aphids were reared in polyvinyl chloride (PVC) plastic cages in a growth chamber at $20^{\circ} \mathrm{C}$ under light: dark (16:8 h) conditions.

\section{Virus acquisition and transmission}

Aphid colonies were kept on infected plants for $48 \mathrm{~h}$ to provide access to the virus. Twenty days after sowing at 23 leaf stage, $R$. padi were then placed on all plants in the field (5 viruliferous aphids/plant) to ensure inoculation. The aphids were killed 3 days later with a non-systemic insecticide spray, to avoid their multiplication and their effect as pests. Fifteen days later, BYDV-PAV presence in inoculated plants was confirmed by the tissue blot immunoassay (TBIA) test (17).

\section{Data collection}

Data was collected from an area of $1 \mathrm{~m}^{2}$ in the center of each experimental plot. In order to estimate the infection rate, the number of infected plants per100 tested plants was measured. Plant height $(\mathrm{cm})$, biomass $\left(\mathrm{g} / \mathrm{m}^{2}\right)$, grain yield $\left(\mathrm{g} / \mathrm{m}^{2}\right)$ and thousand kernels weight $(\mathrm{g})$ were also determined.

\section{Data analysis}

The adopted model was a split-plot experimental design as $y_{i j(k)}=u+R_{i}+T_{j}+e(a)+C_{k}+(T x C)_{j k}+e(b)$ Where $y_{i j k}$ is the response of the effectiveness of the treatment $(j)$ in the replicate (i) for the corresponding cultivar (k); Ri, $T_{j}$, e(a) and $C_{k}$ refers to block effect, treatment effect, errors related to treatment and cultivar effect, respectively. $(\mathrm{TxC})_{\mathrm{jk}}$ and $\mathrm{e}(\mathrm{b})$ represent the interaction cultivar $\mathrm{x}$ treatment and associated experimental error. ANOVA and least significant differences (LSD)-test at $\mathrm{P}=0.05$ using SAS 9.1 software were used to analyze the data.

\section{Results}

Analysis of variance (ANOVA) showed a highly significant $(\mathrm{P}=0.001)$ effect of the interaction between treatment and cultivars on infection rates (INF), biomass yield (BM) and grain yield $(R G)$, and significant $(P=0.05)$ effect on stem height $(\mathrm{H})$ (Table 1$)$.

\section{Evaluation of the interaction between seed treatment and cultivars}

Effect on infection rates - Seed treatment with imidacloprid affected BYDV-PAV incidence regardless of applied doses (Figure 1). For the four varieties, a significant decrease in the infection rate was observed with concentrations of 0.7 and $1.4 \mathrm{~g}$ a.i $/ \mathrm{kg}$ seed. After treatment, infection rate was $30.65 \%, 10.34 \%, 32.33 \%$ and $25.34 \%$ for the varieties Cyclon, QB813-2, Manel and Rihane, respectively. No significant difference was found for using a concentration higher than $1.4 \mathrm{~g}$ a.i $/ \mathrm{kg}$ seed.

Effect on plant height - As can be seen in Figure 2-A, except for Manel, BYDV-PAV infection reduced plant height of all cultivars tested significantly. The imidacloprid treatment at the concentrations of 1.4 and $2 \mathrm{~g}$ a.i $/ \mathrm{kg}$ seed reduced the effect of BYDV-PAV making it not significantly different when compared with the healthy control. The average plant height for the susceptible variety Cyclon was $40 \%$ less compared to that of the control. In 
response to $0.7,1.4$ and $2 \mathrm{~g}$ a.i $/ \mathrm{kg}$ seed treatments, the plant height increased by 50, 90 and $100 \%$, respectively.

Effect on biomass - The imidacloprid treatment impact on biomass was also affected by the applied concentration and the tested cultivars (Figure 2-B). Except for the resistant variety QB813-2, a significant biomass increase was observed among treatments. However, the concentration 0.7 $\mathrm{g} / \mathrm{kg}$ was not sufficient to protect the susceptible cultivar Cyclon from BYDV-PAV infection. The same results were found for Tunisian varieties Manel and Rihane.

A highly significant effect for applying imidacloprid at $1.4 \mathrm{~g} \mathrm{a} . \mathrm{i} / \mathrm{kg}$ seed on biomass was obtained for the three BYDV-PAV sensitive cultivars, Cyclon, Manel and Rihane. In fact, seed treatment had simultaneously decreased viral infection and increased biomass yield by 93.33, 65.40 and $50.90 \%$ for Cyclon, Manel and Rihane, respectively. No difference was found between the effects of 1.4 and $2 \mathrm{~g}$ a.i/kg seed concentrations.

Effect on grain yield - Seed-treatment of the susceptible variety Cyclon at the concentration $0,0.7$ and $1.4 \mathrm{~g} \mathrm{a} . \mathrm{i} / \mathrm{kg}$ seed led to a significant increase in grain yield by 84.30 , 175.30 and $317.33 \mathrm{~g} / \mathrm{m}^{2}$, respectively (Figure 2-C). In addition, grain yield increase of 37.66 and $32.10 \%$, respectively, for Manel and Rihane cultivars was obtained in response to 0.7 and to $1.4 \mathrm{~g}$ a.i $/ \mathrm{kg}$ seed treatment. The BYDV resistant variety QB 813-2 did not show significant increase in grain yield in response to seed treatment.

Effect of imidacloprid treatment and cultivars on thousand kernels weight (TKW) - The effect of imidacloprid treatment on the thousand kernels weight was obtained only for the Cyclon and Manel cultivars (Figure 2D). For cv. Cyclon, significant increase of this parameter was obtained in response to the concentration $0.7 \mathrm{~g}$ a.i $/ \mathrm{kg}$ seed, but was not comparable to the uninfected plants (control) at the concentration $1.4 \mathrm{~g}$ a.i $/ \mathrm{kg}$ seed. For the Manel variety, there was a tendency for the TKW increase in response to treatment concentration, however, the difference was only significant in response to the concentration $1.4 \mathrm{~g}$ a.i $/ \mathrm{kg}$ seed for the inoculated and untreated plants.

Table 1. Mean square of plant height (H), biomass (BM), grain yield (GY), thousand kernels weight (TKW) and infection rate (INF) of the tested barley cultivars Cyclon, QB813-2, Manel and Rihane.

\begin{tabular}{lcccccc}
\hline Source of Variation & $\mathbf{D F}$ & $\mathbf{H}(\mathbf{c m})$ & $\mathbf{B M}(\mathbf{g}) \mathbf{m}^{\mathbf{2}}$ & $\mathbf{G Y}(\mathbf{g}) / \mathbf{m}^{2}$ & $\mathbf{T K W}(\mathbf{g})$ & $\mathbf{I N F}(\%)$ \\
\hline Replicationss $(\mathrm{R})$ & 2 & $5,417^{\mathrm{ns}}$ & $31453,850^{*}$ & $5531,89^{* *}$ & $4,122^{* *}$ & $29,617^{\mathrm{ns}}$ \\
Treatments(T) & 4 & $338,958^{* *}$ & $826360,21^{* *}$ & $114048,13^{* *}$ & $5,814^{* *}$ & $14845,475^{* *}$ \\
E(a) & 8 & 14,271 & 2423,496 & 567,24 & 0,469 & 20,138 \\
Cultivars(V) & 3 & $933,333^{* *}$ & $953840,46^{* *}$ & $72076,05^{* *}$ & $165,753^{* *}$ & $237,617^{* *}$ \\
TxV & 12 & $40,625^{*}$ & $53913,531^{* *}$ & $6724,62^{* *}$ & $0,813^{\mathrm{ns}}$ & $83,908^{* *}$ \\
E(b) & 30 & 17,500 & 8083,300 & 1827,92 & 0,770 & 17,167 \\
\hline
\end{tabular}

* Significantly different at $\mathrm{P}=0.05$; ** significantly different at $\mathrm{P}=0.01 ; \mathrm{ns}=$ not significantly different at $\mathrm{P}=0.05$.

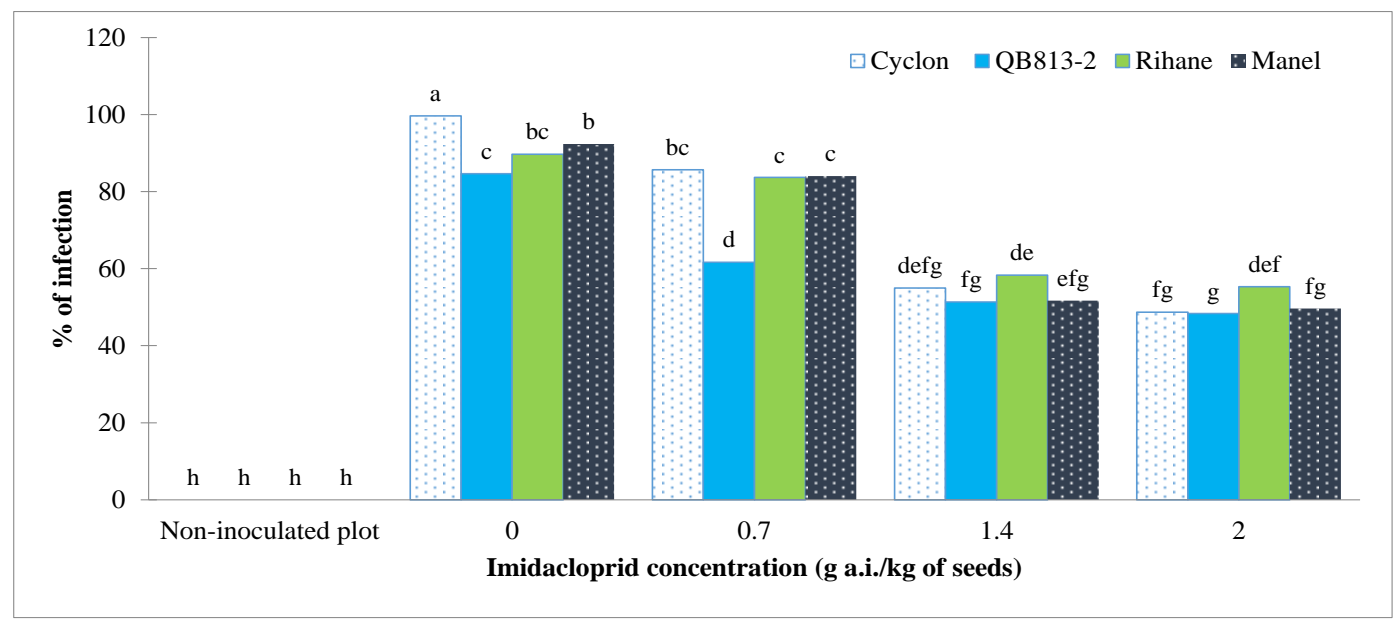

Figure 1. Effect of seed treatment with Imidacloprid insecticide on Barley yellow dwarf virus-PAV (BYDV-PAV) infection $(\%)$ on four barley cultivars (Cyclon, QB813-2, Rihane and Manel). Bars with similar letters are not significantly different at $\mathrm{P}=0.05$. 


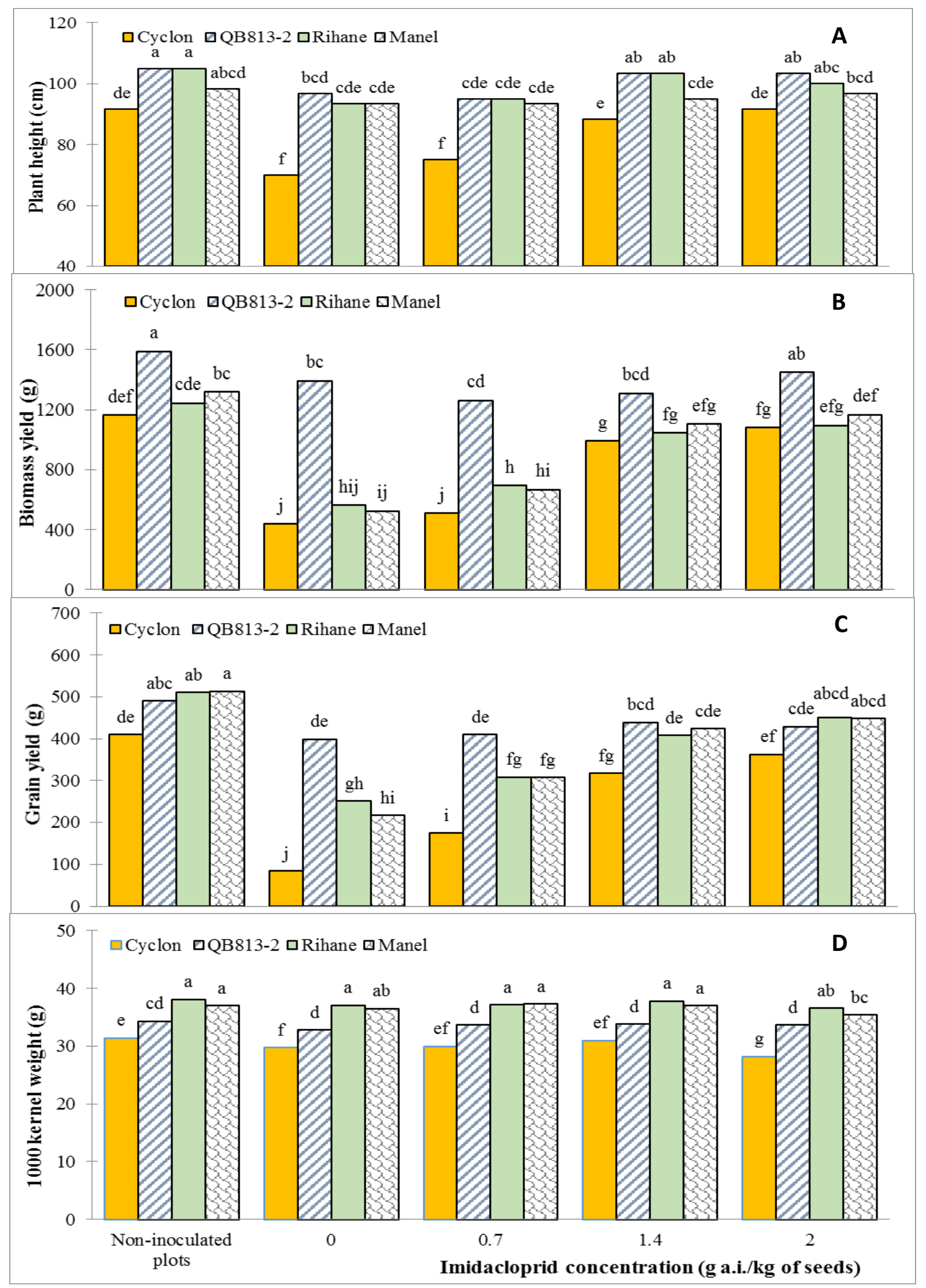

Figure 2. Effect of seed treatment with Imidacloprid insecticide on plant height (A), biomass (B), grain yield (C) and thousand kernel weight (D) of four barley cultivars (Cyclon, QB813-2, Rihane and Manel) after infection with Barley yellow dwarf virus-PAV (BYDV-PAV). Bars with similar letters for each trait are not significantly different at $\mathrm{P}=0.05$. 


\section{Discussion}

This study documents for the first time in Tunisia, the efficiency of imidacloprid as seed treatment to control BYDV-PAV under field conditions. Imidacloprid seedtreatment reduced BYDV-PAV infection in both resistant (QB 813-2) and susceptible barley cultivars (Cyclon, Manel and Rihane). Several earlier studies reported the efficiency of imidacloprid in reducing BYDV infection in cereals (10, $11,26)$. Other studies related to the effect of imidacloprid seed-treatment also reported the efficacy of imidacloprid in reducing Potato leafroll virus (27), and Sugar yellows virus (12) infection.

Imidacloprid seed-treatment resulted in a significant reduction in BYDV-PAV infection when 1.4 ga.i/ kg seed treatment was used, whereas no further significant effect was obtained with $2 \mathrm{~g}$ a.i $/ \mathrm{kg}$ seed treatment. The same concentration did show a significant effect on biomass and yield of the susceptible cultivars. Therefore, the use of imidacloprid seed-treatment at $1.4 \mathrm{~g}$ a.i $/ \mathrm{kg}$ of seeds to reduce $B Y D V$ incidence in barley fields seems to be an appropriate concentration to be used by farmers in years of high BYDV incidence. In this study, the use of higher concentration was found not necessary and consequently not recommended. This finding is in agreement with an earlier study (18), where they reported that seed dressing with imidacloprid at $1.4 \mathrm{~g}$ a.i./kg seed has effectively reduced the incidence of Bean leafroll virus and Faba bean necrotic yellows virus in faba bean and lentil crops under both glasshouse and field conditions.

The use of imidacloprid as seed or foliar-treatment against aphids has been previously investigated $(8,11,15)$. In this study, only the application of imidacloprid as seedtreatment to control primary infection of BYDV-PAV transmitted by $R$. padi during fall, was investigated. A significant effect of the adopted treatment to reduce BYDVPAV incidence and improve both biomass and yield was highlighted. This is consistent with an earlier study (26) that demonstrated no significant difference on BYDV incidence in wheat between using imidacloprid seed-treatment alone and seed-treatment followed by seven foliar insecticide applications.

Even though imidacloprid has shown to be efficient against virus vectors, the residual effect of this systemic insecticide after seed treatment has been always a concern. In this study, the residual effect of imidacloprid in barley was not considered. However, a study previously performed (22) has shown that there is no residual effect after seedtreatment with the systemic neonicotinoids in cereal crops such as wheat.

The use of chemical insecticides remains an important component of pest control. However, the need for ecofriendly control approaches remains an important aspect to be adopted within the integrated pest management context. The use of resistant cultivars to the virus would always be the most practical and cost effective mean for BYDV management, as long as the resistance genes have the ability to express themselves in the target environment. This is the case of the $Y d 2$ gene, which has shown effectiveness in international barley breeding programs for resistance to BYDV (9). In the absence of resistant cultivars and in regions of high risk of BYDV epidemic, seed treatment with imidacloprid may further reduce the primary and secondary spread of BYDV in cereal producing regions.

\section{Acknowledgement}

This study was supported by the Ministry of Higher Education and Scientific Research.

نجار، أسما، إبتسام بن فقيه، هاجر بن غانم، صفاء غسان قمري وأرفيند فارساني. 2017. إدارة فيروس اصفرار وتقزم الشعير - PAV عن طريق معاملة البذور بالمبيد الحثري إيميداكلوبريد. مجلة وقاية النبات العربية، 35(3): 178-184. هدف هذا البحث التحقق من فعالية المبيد الحشري إيميداكلوبريد لدى معاملة البذور به قبل الزراعة في تقليل نسبة الإصابة بفيروس اصفرار وتقزم الشعير على محصول الشعير • أجريت العدوى الاصطناعية بفيروس BYDV-PAV) PAV لصنف شعير مقاوم (BD 813-2) وثلاثة أصناف حساسة (منال، ريحان وسايكلون) تحت الظروف الحقلية بوساطة حشرات منّ الثوفان Rhopalosiphum padi. عوملت البذور بمبيد إيميداكلوبريد في ثلاثة تراكيز 0.7، 1.4 و 2 غرام مادة فعالة/كغ بذور • بعد الإعداء، تم متابعة نسبة الإصابة بالفيروس على الأصناف المستخدمة، كما تم قياس عوامل النمو مثل طول النبات والكتلة

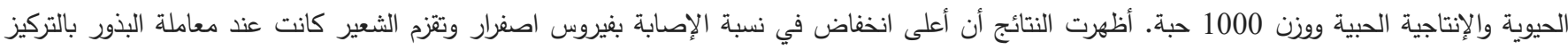

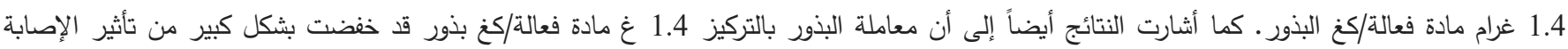

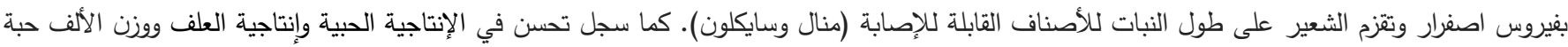

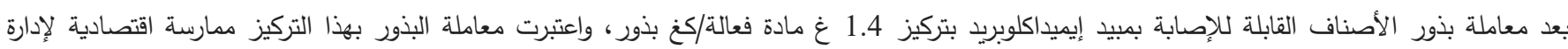
فيروس اصفرار وتقزم الثعير على محصول الثعير تحت الظروف الحقلية، خاصة في المواقع التي تكون نسبة الإصابة بالفيروس عالية.

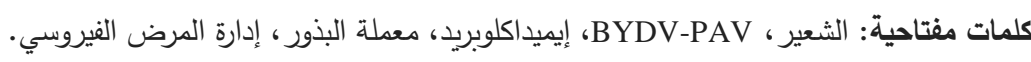

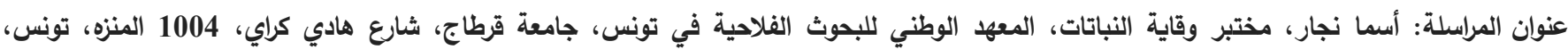
البريد الإكتروني: asmanajara@yahoo.fr
} 


\section{References}

1. Altmann, R. 1991. Gaucho® ${ }^{\circledR}$ einneuesInsektizidzurBekaKmpfung von RubenschaKdlingen. Pflanzenschutz-Nachrichten Bayer, 44: 159-174.

2. Bouallegue, M., M. Mezghani-Khemakhem, D. Bouktila, H. Makni and M. Makni. 2014. Molecular characterization of barley yellow dwarf virus in Tunisia, Acta virologica, 58: 214-222.

3. Balazs, F., M. Malesevic and A. Mesterhazy. 1992. Effect of sowing time and plant density on the infection of Yugoslav wheat varieties by barley yellow dwarf virus. Cereal Research Communications, 20: 207-211.

4. Boukhris, S., R. Souissi, E. Turpeau, J. RouzéJouan, M. Fahem, N. Ben Brahim and M. Hullé. 2007. Aphid (Hemiptera: Aphidoidae) diversity in Tunisia in relation to seed potato production. Annales de la Société Entomologique France, 43: 311-318.

5. Comeau, A. 1984. Aphid rearing and screening methods for resistance to barley yellow dwarf Virus in cereals. In: Book of Abstracts, International Workshop on Barley Yellow Dwarf Virus. P.A. Burnett (ed). 1984, CIMMYT, Mexico.

6. D'Arcy, C.J. 1995. Symptomatology and host range of Barley yellow dwarf virus. Pages 9-28. In: Barley Yellow Dwarf: 40 years of progress. C.J. D'Arcy and P.A Burnett (eds). St Paul, M.N, USA.

7. El-Zahi, S.E. and S.A. Aref. 2011. Field evaluation of recommended insecticides to control bollworms on cotton aphid, Aphis gossypiig Glover and their side effect on associated predators. Journal of Pest Control and Environmental Sciences 19: 55-68.

8. El-Naggar, J.B. and N.H. Zidan. 2013. Field evaluation of imidacloprid and thiamethoxam against sucking insects and their side effects on soil fauna. Journal of Pharmacy and Practice Research, 53: 375387.

9. Ford, C.M., N.G. Paltridge, J.P. Rathjen, R.L. Moritz, R.J. Simpson and R.H. Symons. 1998. Rapid and information assays for $\mathrm{Yd}$, the Barley yellow dwarf resistance gene, based on the nucleotide sequence of a closely linked gene. Molecular Breeding, 4: 23-31.

10. Geissler, K. 1989. On the occurrence of vectors of barley yellow dwarf virus on various host plants in the Aschersleben area during 1985 to 1987. Archiv für Phytopath. und Pflanzenschutz, 25: 4-49.

11. Gray, S.M., G.C. Bergstrom, R. Vaughan, D.M. Smith and D.W. Kalb. 1996. Insecticidal control of cereal aphids and its impact on the epidemiology of the barley yellow dwarf luteoviruses. Crop Protection, 15: 687-697.

12. Heatherington, P.J. and R.H. Meredith. 1992. United Kingdom field trials with Gaucho for pest and virus control in sugar beet, 1989-1991. Pflanzenschutz-Nachrichten Bayer, 45: 491-526.
13. Jemec, A., T. Tisler, D. Drobne, K. Sepcic, D. Fournier and P. Trebse. 2007. Comparative toxicity of imidacloprid, of its commercial liquid formulation and of diazinon to a non-target arthropod, the microcrustacean Daphnia magna. Chemosphere, 68: 1408-1418.

14. Liu, F., X. Wan, Y. Xie, S.M. Gray, G. Zhou and B. Gao. 2007. A Chinese isolate of barley yellow dwarf virus-PAV represents a third distinct species within the PAV serotype. Archives of Virology, 152: 1365- 1373.

15. Liang, H., Z. Chun-lin, H. Fang, B. Run-e, L. Yaobin, Y. Feng-ming and H. Zhong-ping. 2015. Effects of imidacloprid and thiamethoxam as seed treatments on the early seedling characteristics and aphid-resistance of oilseed rape. Journal of Integrated Agriculture, 14: 2581-2589.

16. Makkouk, K.M., A. Najar and S.G. Kumari. 2001. First record of Barley yellow dwarf and Cereal yellow dwarf viruses in Tunisia. New Disease Reports, 3: 16.

17. Makkouk, K.M. and S.G. Kumari. 1996. Detection of ten viruses by the tissue-blot. Immunoassays (TBIA). Arab Journal of Plant Protection, 14: 3-9.

18. Makkouk, K.M. and S.G., Kumari. 2001. Reduction of incidence of three persistently transmitted aphid-borne viruses affecting legume crops by seed-treatment with the insecticide imidacloprid (Gaucho $($ )). Crop Protection, 20: 433437.

19. Najar, A. and I. Hamdi and A. Varsani. 2017. Barley yellow dwarf virus in barley crops in Tunisia: prevalence and molecular characterization. Phytopathologia Mediterranea, 56: 111-118.

20. Rochow, W.F. 1982. Dependent transmission by aphids of barley yellow dwarf luteoviruses from mixed infection. Phytopathology, 72: 302-305.

21. Royer, T.A., K.L. Giles, T. Nyamanzi, R.M. Hunger, E.G. Krenzer, N.C. Elliott, S.D. Kindler and M. Payton. 2005. Economic evaluation of the effects of planting date and application rate of imidacloprid for management of cereal aphids and barley yellow dwarf in winter wheat. Journal of Economic Entomology, 98: 95-10.

22. Salem, R.M., E.M. Khalfalla and Y.S. Ibrahim. 1998. Gaucho (Imidacloprid) as a safe compound for aphid management in faba bean and wheat. Journal of Agricultural Sciences, Mansoura University, 23: 1283-1291.

23. Sun, Y.X. and T.X. Liu. 2016. Effectiveness of imidacloprid in combination with a root nitrogen fertilizer applied to tomato seedlings against Bemisiatabaci (Hemiptera: Aleyrodidae). Crop Protection, 80: 56-64.

24. Svanella-Dumas, L., T. Candresse, M. Hullé and A. Marais. 2013. Distribution of Barley yellow dwarf virus-PAV in the Sub-Antartric Kerguelen Islands and 
Characterization of Two New Luteovirus Species. PLOS One, 8: 1-13.

25. Wang, X., S. Chang, Z. Jin, L. Li and G. Zhou. 2001. Nucleotide sequences of the coat protein and read through protein genes of the Chinese GAV isolate of Barley yellow dwarf virus. Acta Virologica, 45: 249-252.

26. Wangai, A.W., R.T. Plumb and H.F. Van Emden. 2000. Effects of sowing date and insecticides on cereal aphid populations and barley yellow dwarf virus on barley in Kenya. Journal of Phytopathology, 148: 33-37.

27. Woodford, J.A. 1992. Effects of systemic applications of imidacloprid on the feeding and survival of Myzus persicae on potatoes and on

Received: July 15, 2017; Accepted: October 29, 2017 transmission of potato leaf roll virus. Pflanzenschutz Nachrichten Bayer, 45:527-546.

28. Van Regenmortel, M.H., M.A. Mayo, C.M. Fauquet and J. Maniloff. 2000. Virus nomenclature : consensus versus chaos. Archives of Virology, 145: 2227-2232.

29. Yu, W., Z. Xu, F. Francis, Y. Liu, D. Cheng, C. Bragard and J. Chen. 2013. Variation in the transmission of barley yellow dwarf virus-PAV by different Sitobion avenae clones in China. Journal of Virological Methods, 194: 1-6.

30. Zhang, L.P., S.M. Greenberg, Y.M. Zhang and T.X. Liu. 2011. Effectiveness of thiamethoxam and imidacloprid seed treatments against Bemisia tabaci (Hemiptera: Aleyrodidae) on cotton. Pest Management Science, 67: 226-232.

تاريخ الاستلام: 2017/7/15؛ تاريخ الموافقة على النشر: 2017/10/29 